\title{
A DISCOURSE ANALYSIS ON SHORT COMMERCIAL ADVERTISEMENT
}

\author{
Cut Irna Liyana \\ Lecture of Faculty of Social and Political Science, Teuku Umar University \\ Email: cut.irnaliyana88@gmail.com
}

\begin{abstract}
Penelitian ini berjudul "Analisis Wacana pada Iklan Komersial Pendek”. Adapun tujuan dari penelitian ini adalah untuk menganalisis struktur wacana yang digunakan pada iklan komersial, untuk mengetahui penggunaan bahasa pada iklan komersial, dan untuk mengetahui teknik persuasi apa yang digunakan pada iklan komersial tersebut. Periklanan adalah salah satu bentuk komunikasi non- personal, yang berkaitan dengan penjualan produk kepada konsumen melalui media massa. Iklan dibagi menjadi berbagai jenis. Dalam penelitian ini, penulis mengkhususkan pada iklan yang bertujuan untuk menjual produk barang atau jasa, yang disebut dengan iklan komersial. Setiap iklan menggunakan bahasa dan teknik tertentu untuk menarik perhatian calon konsumen. Dua komponen itulah yang menentukan kesuksesan iklan komersial. Penelitian ini merupakan penelitian kualitatif yang dilakukan dengan menggunakan metode observasi. Peneliti melakukan pengamatan pada iklan komersial dalam bentuk rekaman video. Guna mempermudah jalannya penelitian, peneliti juga mentranskripsikan narasi iklan komersial tersebut. Langkah terakhir, peneliti menganalisis struktur dan penggunaaan bahasa pada iklan tersebut. Adapun iklan komersial yang dianalisis pada penelitian ini adalah iklan diaper yang sangat terkenal di Indonesia, yaitu iklan Pampers. Berdasarkan analisis data, penulis menemukan bahwa; pertama, struktur dari iklan terdiri dari tiga bagian, yaitu: bagian judul, badan iklan dan penutup. Bagian judul bertujuan untuk menarik perhatian target pasar tertentu, badan iklan menunjukkan hal yang menarik dari produk dan penutup menggunakan teknik penjualan yang halus; kedua, iklan komersial Pampers menggunakan bahasa Inggris nonformal; dan ketiga, teknik persuasi yang digunakan dalam iklan komersial Pampers adalah teknik logos.
\end{abstract}

Kata Kunci : Wacana, Struktur, Persuasif, Bahasa, Iklan Komersial.

\section{INTRODUCTION}

"Advertisements are selling us something else besides consumer goods: in providing us with a structure in which we, and those goods, are interchangeable, they are selling us ourselves"

\section{Judith Williamson}


Language is an essential part in human being's life. Through language, people can communicate with others. Crystal (1992) defined language as the systemic, conventional use of sounds, signs or written symbol in a human society for communication and selfexpression. Language has a great impact to human's life and their behavior. This is mainly true in the fields of marketing and advertising. In advertising, language as a tool of communication is used to deliver specific messages with the intention of influencing, convincing, and informing people. These specific messages mostly aim to persuade people to buy certain products or service. Language in advertising is very important because it helps people to identify the product. The language of advertising, according to Crystal (1987) is generally laudatory, positive, unreserved, and emphasizing the uniqueness of a product.

At the roof of word 'advertisement' is the verb 'advertee' meaning 'to turn toward' (Goddard, 1998:6). Advertisement is one of media communication that very effective to use as a tool to connect producer and consumer. It deals with promoting certain product to the consumers through mass media. Producer often uses advertisement as a media to promote their product. Because of that, almost all of enterprises that produce new product will use the most interest advertisement to get the profit from the result of selling the product.

In addition, Cook (2001) points out that advertisement inform, persuade, remind, influence and perhaps change opinions, emotions and attitudes. In other words, his contention is that advertisements do not only sell product but change society and make people buy things they do not want or need. He also thinks that advertisement do give warnings or information to people. Hence, advertisement can help create awareness, construct identities and attitudes.

Advertising is not necessarily easy to define, but in general, the concept of advertising can be decided as either commercial or non-commercial. This study focuses on commercial advertising, based on the knowledge that the intended meaning of the advertiser is not only to communicate the concept of a product or service, but also to persuade the viewer to perform a purchase.

Advertisement in television is also known by television commercial that is because advertisement is built to sell goods or services. Certain commercial advertisement has certain language and technique to attract the consumers' attention. To construct a good television commercial, producer has to pay attention to the language use as well as persuasive technique. The language use and persuasive technique in advertisement makes advertisement can be included as discourse.

In linguistic, discourse refers to a unit of language longer than single sentences. More broadly, discourse is the use of written and spoken language in social context. Discourse analysis is the study that analyzes the language used naturally in oral or written. Using of language naturally means language that is used in daily communication. Jorgensen and Philips say that the point of discourse analysis is the study of using language in social context, specially, in interaction among the speaker. The data in discourse analysis is text; it can be oral or written text (Jorgensen and Philips, 2007).

In addition, discourse and discourse analysis are terms that are frequently used by researchers interested in giving language an important place relative to social, political, and cultural formations. The 'postmodern turn' is closely associated with the 'linguistic turn' and the turn to language emphasis research topics that include conversational structure, people stories and narratology, the subtleties of implied meanings, and how language might interact with non- linguistic (e.g. visual) communication.

The study of advertising as discourse is not the new matter. For example, Cook's (1992) text The Discourse of Advertising explores theories of linguistic and poetic in the 
study of advertising. Similarly, Myers' (1994) book Words in Ads examines the verbal language of advertising, including sentence constructions, the use of pronouns, metaphors, punning and the construction of slogans. Analyzed the discourses of advertisement was using a large empirical study as a means of investigating their cultural meanings. Advertising as a type of discourse can be seen in a number of other publications especially in relation to 'ideology'.

However, while there are numerous study of advertising as discourse, discourse of advertisement is still important and interested to be analyzed. The discourse of advertisement is interested to be analyzed because advertisement can change the candidate of consumer behavior, that firstly does not interest to read or listen an advertisement to be interest in it. Even candidate of consumer can be influenced to use the product that is advertised. Due to the fact, the writer is interested to analyze one of a short diapers commercial advertisement in television, which is called Pampers.

Pampers is one of diapers brand that very famous in Indonesia. Pampers is an American brand of baby and toddler product marketed by Procter and Gamble that was found in 1961. Cause of this diaper exists in long time old; people often call other brand of diaper with pampers. For selling the product, pampers is marketed in various ways, such as print advertisement and television commercials. Print advertisements often appear in magazines and other periodicals. Television commercials appear during soap operas produced by Procter and Gamble.

In this paper, the writer would like to analyze a Pampers commercial advertisement in three parts. Firstly, it is about the structure of the commercial advertisement discourse. Secondly, it describes the language use in the advertisement. Finally, it is about the kind of persuasive technique that is used in the commercial advertisement.

\section{METHODOLOGY}

Research method is deal with how the research will be done, including materials of research, instruments, the way of research, variable and data which is providing, and data analysis (Mahsun, 2011: 72). The research of a discourse analysis on short commercial advertisement is qualitative research with observation method was conducted. Procedures of research that was used are data collecting, data analysis, and the exposure of result. Data which is used in this research is Pampers commercial advertisement. Researcher observes commercial television by analyzing recorded television commercial. She also makes the transcript of Pampers commercial advertisement to ease the observation. By conducting this research, the researcher intends to observe the structure of commercial advertisement, the language use, and persuasive techniques. To analyze the structure of commercial advertisement, theory of Bolen (1984) is used. Language use in Pampers commercial advertisement was analyzed by using variation of language based on grammatical rules while persuasive technique was analyzed by using Aristoteles's theory of modes of persuasion.

\section{DISCUSSION}

\subsection{Structure of Pampers Advertisement}

Bolen (1984) claimed that an advertisement has three main parts; they are headline, body and closing. Each part has different function with others. Headline in an advertisement, that must attract consumers' attention, has several forms and purposes. They are headline as statement, question, news, testimony, attract certain target, and content of certain emotion. Body in an advertisement has criteria that show; the emotion, gift, 
monolog and dialog form, the excitement of product, and testimony form. For closing, commonly use soft selling technique.

Transcript of Pampers advertisement:

You've just learned to walk. But it will be risk reached before you were caught walk out up how to stop. This is just found by you.That's why love pampers new active fit it's now shaped. To fit more naturally between the legs and exceptional dryness. To help you keep going until you find a way to stop. Naturally shape to fit. Active it. Inspired by babies, created by pampers.

From the text, the writer can analyze that:

Headline of the advertisement is "You've just learned to walk". The headline form is a headline that attracts attention from certain target market. The use of word "you" in this headline is referring to people who just learned to walk. It means that babies who have been born and just learned to walk. In discourse analysis, this kind of reference is called exophora. Halliday and Hasan (1976: 33) defined exophora as a reference that refer to things out of the text (extra textual). Exophora is analyzed by situational context. However, although the used of word is referred to babies, but the target of the advertisement is not really to babies. We know that babies are not able to buy something yet. So, it is shown from headline; it limits the target market just for mothers or mothers-to-be that have child or babies and need diapers.

Body of the advertisement above divided into six sentences;

(1)This is just found by you

(2)That's why love pampers new active fit it's now shaped.

(3)To fit more naturally between the legs and exceptional dryness.

(4)To help you keep going until you find a way to stop.

(5)Naturally shape to fit.

(6) Active it".

From the sentences, it can be analyzed that the body of pampers advertisement above shows a monolog; it was not a conversation. There is no interlocutor in the spoken text, just a narrator who exposes the text. Then, sentences of the body of the advertisement also show the excitement of the product and attract consumers to use it. It can be found in each sentences of body advertisement. The using the word This in first sentences is referred to problem that was exposed in sentence before and the word 'you' is referred to target market. In this sentence, advertisement makers make sure that the risk of the problem just found by mother who has baby that just learned to walk. In second sentence, the advertisement maker tries to convince costumers or readers of the the pampers's reason. Then, sentence (3) and (4) of body Pampers advertisement shows that the advertisement maker tries to explain some purposes or aims of the product. Whereas sentence (5) of body advertisement indicated that the advertisement maker tries to show the advantages of the product.

Closing of the advertisement is presented in tagline "Inspired by babies, created by pampers". Through this sentence, the advertisement maker want to persuade the consumer that pampers is created for babies and created because of babies' need. This 
advertisement uses soft selling technique or in other word, indirect selling technique in closing. This closing type has character as reminder target consumer of the product when they need it.

\subsection{The Language Use in Pampers Advertisement}

Based on Cambrigde Dictionary, language is divided into formal and informal language. Formal language is used in situations that are serious or that involve people we do not know well. Language of advertisement commonly uses informal language. Producers tend to use interesting sentence to publish their product. Pampers advertisement, as English commercial advertisement, also uses informal language when delivered the advertisement to the public. The informal words are found in the condensation or contraction format. Based on Cambridge Dictionary, the using of condensation or contraction in the text or sentences is indicated as informal language. They are showed in explanation below:

Transcript of Pampers advertisement:

You've just learned to walk. But it will be risk reached before you were caught walk out up how to stop. This is just found by you. That's why love pampers new active fit it's now shaped. To fit more naturally between the legs and exceptional dryness. To help you keep going until you find a way to stop. Naturally shape to fit. Active it. Inspired by babies, created by pampers.

Condensations in the text:

$$
\begin{array}{ll}
\text { You've, } & \text { it should be }=\text { you have } \\
\text { That's, } & \text { it should be }=\text { That is } \\
\text { it's, } & \text { it should be }=\text { it is }
\end{array}
$$

Beside the use of condensation or contraction, other point of informal language is the using of ellipsis. Ellipsis is commonly found in informal text. Ellipsis happens when we leave out (in other words, when we don't use) items which we would normally expect to use in a sentence if we followed the grammatical rules.Halliday and Hasan (1976:42) stated that at least there are two kind of ellipsis in discourse; they are nominal ellipsis and verbal ellipsis. He also describes ellipsis as substitution by zero. In this Pampers advertisement, there are found ellipsis in some sentences; they are as follows:

(1)To fit more naturally between the legs and exceptional dryness.

(2)To help you keep going until you find a way to stop.

(3) Inspired by baby, created by Pampers.

Ellipsis that is found in the sentences of the advertisement is in subject and predicate. In the first sentence, there are no subject and verb in this sentence. As normal structure in formal language, each sentence should has at least subject and verb. So, for this sentence, it should be :

"Pampers is created to fit more naturally between the legs and exceptional dryness." 
This condition also found in sentence (2) and (3). There are no subject and verb in these sentences. These sentences should be:

Pampers is created to help you keep going until you find a way to stop. Pampers is inspired by baby, it is created by Pampers.

\subsection{Persuasive Technique in Pampers Advertisement}

Commercial advertisement has language and technique to attract attention of consumer. According to Aristoteles, the point of communication is persuasion; it means that communication that occurs when a speaker delivered the speech to listeners in changing their attitude. To catch the consumer's attention, producer uses various persuasive techniques, which are including in three main techniques according to Aristoteles in Nurjannah (2012), they are: ethos, pathos and logos.

The first technique is advertisement with stressing in Argument Based in Credibility (ethos). Ethos is invitation or directive by communicator who has credibility as an expert in the field. This kind of technique is used to give suggestion and compensation with shows new idea or perpetuation of company.

The second technique is advertisement with stressing in Psychological/ Emotional Argument (pathos). Pathos means delivering the message used emotion effect; such as funny advertisement, humor and makes listeners memorize it. This technique has characteristics involving certain emotion aspect to get consumer's interest. It is related to the existence of commercial itself and looks down to others product.

The third technique is advertisement with stressing in Logical Argument (logos), which is informative and based on rationalization of systematic idea to make consumer believe in product quality (Agustrijanto. 2006). Logos also deliver invitation by giving the argumentation of data.

Picture 1. Modes of Persuasion

ETHOS

credibility, authority, reliability

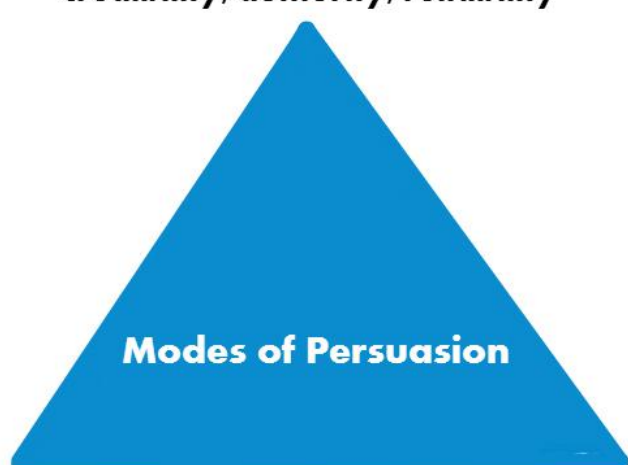

PATHOS

LOGOS

emotion, imagination, sympathy

logic, reason, rationality

Source: Kibin.com 
Considering three characteristics above, Pampers advertisement tends to include in advertisement that uses stressing in logos unsure. It can be showed in the transcript:

You've just learned to walk. But it will be risk reached before you were caught walk out up how to stop. This is just found by you. That's why love pampers new active fit it's now shaped. To fit more naturally between the legs and exceptional dryness. To help you keep going until you find a way to stop. Naturally shape to fit.Active it. Inspired by babies, created by pampers.

The sentences in this advertisement are informative and standard advertisement language. The advertisement does not look down to others product, does not use the famous figure to advertise their product or mention the image of company.

\section{CONCLUSION}

Certain commercial advertisement has certain language and technique to attract the consumers' attention. To construct a good television commercial, producer has to pay attention to the language use as well as persuasive technique. Pampers advertisement is aim to persuade consumers by using persuasive language. After analyzing the discourse of Pampers commercial advertisement, the writer can conclude that the advertisement can be analyzed in structure, the language use, and persuasive technique. In structure, the headline of advertisement tends to attract attention of certain target market, the body shows monolog and the excitement of product and the closing uses soft selling technique. The language that is used in Pampers advertisement is informal English, it has several condensations format and ellipsis in some sentences. In addition, the advertisement uses persuasive technique that stressing in logos.

\section{REFERENCES:}

Agustrijanto. 2006. Copywritting: Seni Mengasah Kreativitas dan Memahami Bahasa Iklan. Bandung: Remaja Rosdakarya.

Andrew Jardine .2004. "A Discursive Analysis of a Television Advertisement: the I'D Like Advertisement For Xenical", in GCB - Gender and Consumer Behavior Volume 7, eds. Linda Scott and Craig Thompson, Madison, WI : Association for Consumer Research. http://acrwebsite.org/volumes/12076/gender/v07/GCB-07 accessed on Oct $13,2016$.

Bolen, William H. 1984. Advertising. New York: John Wiley \& Son.

Brown, Gillian \& Yule, George. 1983. Discourse analysis, United Kingdom: Cambridge University press. 
Chaer, Abdul dan Leony Agustina. 2004. Sosiolinguistik: Suatu Perkenalan Awal. Yogyakarta: Rhineka Cipta.

Cook, Guy. 2001. The Discourse of Advertising, 2nd edition,. New York: Routledge.

Crystal, David. 1987. The Cambridge Encyclopedia of Language. New York: Cambridge University Press.

De Beaugrande, R-A and Dressler, W.U. 1981. Introduction to Text Linguistics. New York: Longman.

Goddard, Angela. 1998. The Language of Advertising, New York: Routledge.

Fairclough, Norman. 1997. Critical Discourse Analysis: The Critical Study of Language. New York: Longman Group.

Halliday, Michael and Ruqaiya Hasan. 1976. Cohesion in English, London: Longman.

Halliday, M.A.K. 1994. Bahasa, Konteks dan Teks: Aspek-aspek Bahasa dalam Pandangan Semiotik Sosial (Terjemahan Asruddin Barori Tou). Yogyakarta: Gadjah Mada University Press.

Holmes, Janet. 1992. An Introduction to Sosiolinguistics. New York: Longman.

http://kibin.com//pictures//modesofpersuasion. Accessed on October 20, 2016.

http://dictionary.cambridge.org/grammar/formal and informal language. Accessed on October 20, 2016

Jorgensen, Marianne W. and Louise J. Philips. 2007. Analisis Wacana: Teori dan Metode. Yogyakarta: Pustaka Pelajar.

Kalsson, Sofia. 2015. Advertising as Discourse: A study of print advertisements published in The New Yorker (Bachelor Thesis). Sweden: Linaeus University. http://www.diva-portal.org. accessed on October 2, 2016.

Leech, G. N. 1966. English in advertising: A Linguistic Study of Advertising in Great Britain, London: Longman

Mahsun .2011. Metodologi Penelitian Bahasa: Tahapan Strategi, Metode, dan Tekniknya. Jakarta: PT. Raja Grafindo

Nurjannah. 2012. Etika Komunikasi Persuasif '7 Teknik Persuasif'. Riau: UNRI.

Sholikhah, Ika Maratus. 2010. Wacana Iklan Komersial Berbahasa Indonesia dan Inggris di Televise. Unpublished Thesis. Yogyakarta: Universitas Gajah Mada

Sheperd, Joseph W. 1994. Advertising and Language; The War of Words Between Copywriters and Language Purists. The faculty Journal of Aichi Gakuin Junior College No. 6 edition March. Nagoya, Japan. http://iteslj.org. accessed on October 20, 2016

Tannen, D. (ed.). 1993. Framing in Discourse. New York and Oxford: Oxford University Press. 
Yule, George. 1996. Pragmatics: Oxford introductions to Language Study, Oxford University Press.

www.youtube.com//jinggleiklan//pampersbabieswalk. Accessed on October 17, 2015. 